\title{
Rethinking the Refuge
}

\section{A Systemic Approach to Huguenot Communities in the Dutch Republic}

\author{
Chrystel Bernat \\ Institut protestant de théologie, Faculté de Montpellier, Montpellier, France \\ and Laboratoire d'études sur les monothéismes (UMR 8584 CNRS-EPHE), \\ Campus Condorcet, Aubervilliers, France \\ chrystel.bernat@gmail.com
}

David van der Linden

Radboud Universiteit Nijmegen, Nijmegen, The Netherlands

d.vanderlinden@let.ru.nl

\begin{abstract}
The history of the Huguenot Refuge in the Dutch Republic has often been written from a strictly national and confessional perspective, with little attention paid to the connections between French Protestants and other religious communities. In recent years, however, scholars from fields other than religious history have begun to explore the impact of the Huguenot Refuge, while historians of migration have compared the Huguenots to other minorities. Building on these new directions, this special issue seeks to move beyond the traditional boundaries of scholarship on the Dutch Refuge. Focusing on untapped archival sources, the relations between the Huguenots and other religious communities, as well as transnational networks of conflict and solidarity, the articles gathered here propose a more systemic approach towards the Huguenot Refuge in the Dutch Republic.
\end{abstract}

\section{Keywords}

refugees - Huguenots - Catholics - Dutch Republic - Walloon churches multi-confessionality - diasporic communities - history of archives 
The flight of French Protestants to the Dutch Republic has always fascinated historians. We can trace the origins of this tradition to the direct aftermath of the revocation of the Edict of Nantes in 1685, when refugee authors began to publish histories on the experience of persecution in France and subsequent flight abroad. As refugee minister Élie Benoist noted in the introduction to his five-volume Histoire de l'Édit de Nantes (1693-1695): "If History be properly devoted to preserve for posterity the memory of the most remarkable things that happen in this world, it cannot be denied that the sorry end of the liberties, which the Reformed have so long enjoyed in France, is one of the most memorable events, which merits to be taken in hand to instruct those in times to come."1 Modern historians have largely followed his account. They have described how the growing discrimination of the Huguenot population during the reign of Louis XIV was followed by the dragonnades in the early 168 os - the quartering of soldiers on Huguenot families to force them to convert to Catholicism - and then the eventual revocation of the Edict of Nantes in October 1685, which caused a mass exodus of Protestants from France. An estimated 35,000 refugees fled to the Dutch Republic, where they joined the French-speaking Reformed communities, the so-called Walloon churches. These churches had been founded in the later sixteenth century by French-speaking Protestants from the Southern Low Countries, known as Walloons, who had escaped Catholic persecution by the Habsburg authorities. This "First Refuge" thus established a vital ecclesiastical framework for the "Second Refuge" of the later seventeenth century. ${ }^{2}$

Undergirding Benoist's history, however, was his conviction that the tyranny of Louis XIV should be set against the benign treatment of the Huguenots abroad, which led him to stress the heroism of the refugees and their contribution to the societies that welcomed them. Scholars echoed Benoist's hagiographical stance at least until the 1980s. On the one hand, historians insisted on the suffering of the Huguenot refugees, presenting them as martyrs because they had shown the courage to remain steadfast in their Protestant faith and

1 Élie Benoist, Histoire de l'Édit de Nantes, contenant les choses les plus remarquables qui se sont passées en France avant \& après sa publication, à l'occasion de la diversité des Religions, 5 vols. (Delft: Adrian Beman, 1693-1695), 3: preface.

2 Recent overviews include Willem Frijhoff, "Uncertain Brotherhood. The Huguenots in the Dutch Republic," in Memory and Identity. The Huguenots in France and the Atlantic Diaspora, ed. Bertrand Van Ruymbeke and Randy J. Sparks (Columbia, 2003), 128-171; Hans Bots, "Le Refuge dans les Provinces-Unies," in La Diaspora des Huguenots. Les réfugiés protestants de France et leur dispersion dans le monde, XVIe-XVIIIe siècles, ed. Eckart Birnstiel and Chrystel Bernat (Paris, 2001), 63-74; David van der Linden, Experiencing Exile. Huguenot Refugees in the Dutch Republic, 1680-1700 (Farnham, 2015). 
flee France. ${ }^{3}$ On the other hand, historians have drawn attention to the decisive influence of the refugees on Dutch society, focusing on the economic, political, and cultural realms. ${ }^{4}$ Within this context, scholars of intellectual history have also paid attention to key figures active in the Dutch Refuge and the wider Republic of Letters, including Pierre Bayle, Pierre Jurieu, Jean Le Clerc, and the Basnage de Beauval brothers. ${ }^{5}$

In recent years, however, the history of the Huguenot Refuge has been profoundly reassessed. In the case of the Dutch Republic, the refugees are no longer presented simply as the heralds of modern thought or the victims of persecution, but understood as migrants who struggled to rebuild their lives far away from their homeland, separated from their friends and family they had left behind. ${ }^{6}$ This historiographical reassessment has also benefited from the interest of scholars beyond the narrow field of Huguenot studies. Since the initial historiographical revisions of the years 1980-2010 the study of the Dutch Refuge has received a particularly stimulating impetus thanks to cross-disciplinary research. No longer in the hands of Huguenot historians alone, the Dutch Refuge is currently also explored by art historians, musicologists, and literary historians, who approach the Huguenot refugees from perspectives other than the strictly religious. In this research, French exiles occupy a prominent place in wider socio-cultural transnational transfers, in particular the circulation of French music, the spread of French language and literature across Europe, the birth of political news, and the development of anti-French iconography. As such, these scholars have had to engage

3 David van der Linden, "Histories of Martyrdom and Suffering in the Huguenot Diaspora," in $A$ Companion to the Huguenots, ed. Raymond A. Mentzer and Bertrand Van Ruymbeke (Leiden, 2016), 348-370; Bertrand Van Ruymbeke, "Le Refuge. History and Memory from the 1770s to the Present," in A Companion to the Huguenots, 422-441.

4 Hendrik Jacob Koenen, Geschiedenis van de vestiging en den invloed der Fransche vluchtelingen in Nederland (Leiden, 1846); Willem Ernst Johan Berg, De réfugiés in de Nederlanden na de herroeping van het Edict van Nantes. Eene proeve naar den invloed, welken hunne overkomst gehad heeft op handel, nijverheid, letteren, beschaving en zeden (Amsterdam, 1845); Hans Bots, G.H.M. Posthumus Meyjes, and F. Wieringa, Vlucht naar de vrijheid. De hugenoten en de Nederlanden (Amsterdam, 1985).

5 See especially Gerald Cerny, Theology, Politics, and Letters at the Crossroads of European Civilization.Jacques Basnage and the Baylean Huguenot Refugees in the Dutch Republic (Dordrecht, 1987); Jens Häseler and Antony McKenna, ed., La Vie intellectuelle aux Refuges protestants (Paris, 1999); Hubert Bost, Pierre Bayle (Paris, 2006); Mara van der Lugt, Bayle, Jurieu and the Dictionnaire Historique et Critique (Oxford, 2016); Maria Cristina Pitassi, Entre croire et savoir. Le problème de la méthode critique chez Jean Le Clerc (Leiden, 1987).

6 Van der Linden, Experiencing Exile (see above, n. 2); Carolyn Chappell Lougee, Facing the Revocation. Huguenot Families, Faith, and the King's Will (Oxford, 2017). 
with the historiography of French Protestantism, in order to better understand the link between the phenomena they study and the Huguenot diaspora. ${ }^{7}$

Within the field of religious history, we can also detect a "comparative turn," as scholars have come to acknowledge that the Huguenot diaspora should be studied from a transnational, even global angle. Until fairly recently, most histories on the Huguenot diaspora were written along strictly national boundaries, relying on archives in one particular country to chronicle the history of the refugee community in a single nation. As a result, scholars often viewed exile as a one-way street, leading to the gradual integration and assimilation of refugees into their host nation - a linear trajectory "from strangers to citizens." Another consequence was that historians often ignored the long-distance ties that still bound refugees to the families and friends they had left behind in France, or the bonds forged between refugees across the Huguenot diaspora. This tendency has been challenged by the works of Susanne Lachenicht, Ullrich Niggeman, and most recently Owen Stanwood, who have compared the Huguenot exile experience across the European and colonial world. ${ }^{8}$

The comparative approach in refugee studies has also resulted in studies that seek to understand the Huguenot Refuge as part of the wider phenomenon of early modern exile movements. ${ }^{9}$ As Pierre Bayle noted, the multi-confessional Dutch Republic was the "great ark of the refugees," a safe haven for religious refugees of all persuasions, including Calvinists from the Southern Netherlands, Puritans from England, Jews from the Iberian Peninsula, and Lutherans from Bohemia and Austria. It is somewhat surprising that scholars have only recently begun to explore the connections between these refugees, who, they

7 See especially Rebekah Ahrendt, "Armide, the Huguenots, and The Hague," Opera Quarterly 28 (2012), 131-158; Rebekah Ahrendt, "A Huguenot impresario in the Dutch Republic," European Drama and Performance Studies 4 (2015), 17-36; Marion Brétéché, Les compagnons de Mercure. Journalisme et politique dans l'Europe de Louis XIV (Seyssel, 2015); Isaure Boitel, L'image noire de Louis XIV. Provinces-Unies, Angleterre (1668-1715) (Seyssel, 2016); Alisa van de Haar, The Golden Mean of Languages. Forging Dutch and French in the Early Modern Low Countries (Leiden, 2019); Rebekah Ahrendt, "Les foyers d' activité musicale et théâtrale en Europe vers 1700. Une enquête en coulisses," in Les foyers artistiques à la fin du règne de Louis XIV (16821715). Musique et spectacles, ed. Anne-Madeleine Goulet and Rémy Campos (Turnhout, 2019), 399-416.

8 Susanne Lachenicht, Hugenotten in Europa und Nordamerika. Migration und Integration in der Frühen Neuzeit (Frankfurt, 2010); Ulrich Niggemann, Immigrationspolitik zwischen Konflikt und Konsens. Die Hugenottenansiedlung in Deutschland und England, 1681-1697 (Cologne, 2008); Owen Stanwood, The Global Refuge. Huguenots in an Age of Empire (Oxford, 2020).

9 Nicholas Terpstra, Religious Refugees in the Early Modern World (Cambridge, 2015); Mathilde Monge and Natalia Muchnik, L'Europe des diasporas, XVIe-XVIIIe siècles (Paris, 2019). 
have shown, compared their experiences with those of others and seized upon common narratives of suffering to advance their position in the Dutch Republic. ${ }^{10}$

Building on these recent developments in Huguenot and refugee studies more widely, this special issue proposes that we rethink the history of the Dutch Refuge. What alternative histories emerge if we apply these new perspectives? Underlying the special issue are three main principles: methodological, documentary, and thematic. First of all, the articles gathered here propose that historians should be more sensitive to the interconnections between diasporic societies in the Dutch Republic, including the Huguenot exiles. Wishing to break with the segmented analysis that has long prevailed in studies of the Dutch Refuge, this special issue approaches the Huguenot refugees from a systemic perspective, that is: no longer as a discrete group, but interacting with other expatriate communities and minority groups that were part of the multiconfessional Dutch Republic. It is important to analyse the ways in which the Huguenot refugees interacted with other actors outside of the closed world of their refugee community, probing their relationship with the host society as well as other expatriate groups and refugee communities, and to examine the impact of life in exile on their relations with those Huguenots who had remained in France. In other words, we must take the Dutch Refuge out of its narrow Protestant-centred world, and explore the refugees' life within the complex social and multi-confessional world that surrounded them - both within the Dutch Republic and beyond - and to a large extent conditioned their experience of exile.

The most important community to which French Protestants had to relate in exile was the large Catholic minority living in the Dutch Republic. As Chrystel Bernat shows in her essay, refugee sermons are revealing of the new zones of conflict in exile, in particular the multi-confessional entanglement of the Dutch Republic that refugees had to face. In their sermons refugee ministers frequently drew attention to the dangers of Catholicism, stigmatising their opponents so as to protect their religion from any confessional alteration on the grounds of preserving doctrinal purity, because any form of religious permeability was seen as an overture to the overthrow of the Reformation and a possible rejection of the refugees. Similar tensions can be observed in the French Reformed church of Maastricht, which is the focus of Julien Léonard's article. Situated in an overwhelmingly Catholic city and close to the Principality of

10 Johannes Müller, Exile Memories and the Dutch Revolt. The Narrated Diaspora, 1550-1750 (Leiden, 2016); Geert Janssen, "The Republic of the Refugees. Early Modern Migrations and the Dutch Experience," Historical Journal 6o (2017), 233-252. 
Liège, the French Protestant community had to develop its own survival strategies in the face of Catholic missionary efforts, the occupation of the city by French forces in 1673, and even competition with the Dutch Reformed Church. David van der Linden likewise draws attention to the ongoing struggle between French Protestants and Catholics in the Dutch Republic, which mirrored the conflict in France. His essay explores the efforts of French Discalced Carmelite missionaries in Holland to convert Huguenots to the Church of Rome. Their mission brought them into conflict with the Walloon churches, but was surprisingly successful in converting and repatriating Huguenot refugees to France following the 1697 Peace of Rijswijk.

A second major principle underlying the essays in this volume is to reconsider the sources used to write the history of the Refuge. What sources do we use? And in order to write what type of history? Traditionally, historians have relied on institutional documents produced by the major Walloon churches of Holland, in particular consistory records and synodal resolutions, as well as printed pastoral, polemical, and apologetic literature. The essays in this special issue, however, either seek to broaden the range of sources or to approach them from a different perspective, in order to shed fresh light on the Huguenot experience of diaspora. Both first require a deeper understanding of the ways in which Huguenot history-writing in the Netherlands has been influenced by the sources collected specifically for this purpose. As August den Hollander stresses in his essay, by far the most commonly used sources are to be found in the Walloon library, currently housed in Leiden University Library. By retracing the various stages in which this library-cum-archive evolved over time, he reveals how the particular collection focus and acquisition policies of subsequent curators laid the basis for the hagiographical writing of Huguenot history. Yet as Chrystel Bernat argues, the Walloon archives still yield plenty of documents that can be read against the grain, including manuscript sermons that are notoriously under-studied when compared to the printed pastoral literature produced in the Refuge. As such, her article also draws attention to the importance of the Walloon library for the studying of French religious culture in the Dutch Republic. David van der Linden focuses on the archives of Catholic missionaries and the dispatches of French diplomats to gain an outsiders' view of the Refuge. Studying the interconfessional contacts fostered within the Dutch Refuge, in other words, also requires us to consider sources kept in archives and libraries outside the Netherlands.

Finally, from a thematic perspective, this special issue focuses on the transnational—and often conflictual—links underpinned by the Dutch Refuge. Huguenot refugees not only maintained bonds of kinship with family members who had stayed behind after the Revocation, they also engaged in conflict 
with Catholics living in the Dutch Republic, France, and other territories. As Julien Léonard shows, the theological debates between ministers in the French church of Maastricht and clergy from the nearby Principality of Liège had a long and tortuous history that in fact predated the Revocation. Chrystel Bernat likewise reveals transnational networks in which the refugees were involved from a distance. She discusses the extraterritorial religious struggles concerning proselytes and children from the Southern Netherlands, as well as solidarity towards the Protestants of Lithuania, who were exposed to Catholic extortion. David van der Linden's essay, finally, connects the Counter-Reformation campaign against the Huguenots in France to the efforts of French missionaries in Holland, thus showing how religious struggles in the French heartland spilled over to the Dutch Republic.

Taken together, the articles in this special issue are a first attempt to set a more systemic agenda for studying the Dutch Refuge. We propose to consider the Refuge from a denser diasporic entanglement, exploring the full depth of exile experiences and the diversity of community-rebuilding in a mixed confessional environment. The contributions gathered here will hopefully encourage other scholars to explore a wider array of sources, to compare the Huguenots to other expatriate communities, and to understand their diasporic experience within wider transnational frameworks of religious solidarity and conflict.

\section{Acknowledgments}

The articles gathered in this special issue were presented at the international conference "Repenser le Refuge," held at Leiden University in October 2018 under the aegis of the École pratique des hautes études-Paris Sciences Lettres, with the assistance of the Leiden University Library. The authors would like to thank Anton van der Lem and Judith Pollmann for their help in organising this event. 